Jurnal Scripta Teologi dan Pelayanan Kontekstual
ISSN 2086-5368 (Print)
ISSN
Http://ejournal.stte.ac.id
Vol.2, No.2, pp. 144-157, 2017

\title{
Konsep Puasa Yang Benar Berdasarkan Studi Eksegese Terhadap Yesaya 58:1-12
}

Marlon Butar-butar

STT Ebenhaezer Tanjung Enim, marlonbutarbutar1968@gmail.com

\section{INFO ARTIKEL}

Sejarah Artikel:

Diterima : 02 Okt 2017

Direvisi : 09 Okt 2017

Disetujui: 15 Okt 2017

Dipublikasi: 28 Okt

2017

Kata Kunci:

Konsep, Puasa, Benar,

Yesaya 58: 1-12

Keywords:

keyword one, keyword two, keyword three.

\section{ABSTRAK}

Konsep puasa yang benar haruslah sesuai dengan apa yang dikehendaki oleh Tuhan yang memerintahkan berpuasa. Tentu kitab suci sudah mencatatnya. Namun dalam pelaksanaannya selalu ada masalah, berbagai masalah yang terjadi sekitar berpuasa tidak hanya terjadi pada saat penulisan teks yang diangkat penulis, tetapi juga masa kini. Persoalan itu terjadi karena problem hermeneutika, usaha memahami teks yang berbeda satu dengan yang lain. Karena itu melalui teks Yesaya 58:1-2 penulis akan menguraikan konsep puasa yang dikehendaki Tuhan dalam kehidupan umat Allah, baik dulu maupun sekarang. Tentu ada konteks yang berbeda, karenanya penulis akan berusaha menemukan prinsip-prinsip puasa yang sesuai dengan kehendak Allah, melalui usaha menggali makna teks dengan cara eksegese, hasil eksegese akan dijadikan pokok-pokok pemikiran untuk menjawab semua persoalan mengenai puasa, baik dari teks, maupun persoalan masa kini.

\section{ABSTRACT}

The concept of true fasting must be in accordance with what is desired by God who commands fasting. Of course the scriptures have recorded it. But in its implementation there are always problems, various problems that occur around fasting not only occur at the time of writing the text that the writer raised, but also today. The problem occurred because of hermeneutics problems, attempts to understand texts that differ from one another. Therefore through the text of Isaiah 58: 1-2 the writer will describe the concept of fasting desired by God in the lives of God's people, both past and present. Of course there are different contexts, so the writer will try to find the principles of fasting that are in accordance with God's will, through an effort to explore the meaning of the text by exegesis, the results of the exegesis will be used as main points of thought to answer all issues regarding fasting, both from the text, and current problems. 


\section{Pendahuluan}

Salah satu pengajaran yang terus diperbincangkan dan menjadi pengajaran yang masih relevan pada konteks sekarang adalah tentang puasa. Alkitab telah membahas pengajaran tersebut secara komprehensif baik dari Perjanjian Lama sampai Perjanjian Baru. Puasa dalam Perjanjian Lama yang dilakukan secara rutin oleh bangsa Israel dilatarbelakangi oleh penantian kedatangan Mesias, Penyelamat bangsa Israel yang dijanjikan dalam kitab Taurat dan kitab para nabi. Sedangkan dalam Perjanjian Baru, Mesias telah datang dan berkarya. Artinya Keselamatan sudah datang, dan berpuasa merupakan cara untuk menjaga keselamatan yang sudah dimiliki.

Puasa itu sebagai sesuatu yang sangat baik untuk dilakukan karena puasa merupakan upaya menyatakan kepada Allah, dan kepada diri sendiri, bahwa ada keseriusan dalam menjalin hubungan dengan Allah. Puasa berfungsi untuk menolong seseorang dalam memperoleh perspektif baru dan memperbaharui ketergantungan kepada Allah. Puasa adalah cara untuk memohon belas kasihan Tuhan terlebih dalam situasi yang mendesak, baik dalam hidup sehari-hari maupun dalam pelayanan yang sedang dijalani

Oleh sebab itu, dalam berpuasa perlu melepaskan mata dan keinginan hati dari hal-hal duniawi dengan beralih pusat perhatian kepada Allah. Beberapa orang beranggapan bahwa puasa merupakan jalan pendek untuk memperoleh jawaban doa. Terkadang dianggap sebagai obat manjur untuk segala macam penyakit, untuk memperoleh perlindungan ilahi, untuk memberi penyataan yang lebih jelas, untuk memberi kelepasan dari kuasa Iblis, bahkan untuk menghasilkan kehidupan rohani yang lebih suci.

Doa dan puasa sering dikait-kaitkan (Luk. 2: 37; 5: 33). Dalam praktiknya puasa sering fokus pada aktivitas tidak makan dan tidak minum. Sekalipun berpuasa sering dikaitkan dengan doa, namun puasa harus dipandang sebagai suatu tindakan rohani tersendiri, sehingga berpuasa sering disebut "berdoa tanpa mengucapkan kata-kata". Allah telah banyak menyampaikan pewahyuan kepada manusia demi keberhasilannya dalam menjalani hidup di dunia, namun salah satu kunci utama untuk dapat berhasil dalam hidup adalah puasa. Dalam Alkitab Perjanjian Lama dan Perjanjian Baru telah banyak ajakan untuk melakukan puasa termasuk dengan praktiknya. Bahkan orang Kristen diseluruh muka bumi ini telah melakukan puasa, baik perorangan maupun kelompok.

Dalam perkembangannya, banyak gereja-gereja juga menjadikan puasa sebagai salah satu bagian dari program gerejanya. Gembala, jemaat dan majelis-majelis gereja diharapkan untuk dapat mengikuti setiap kegiatan puasa tersebut. Dengan demikian program puasa dijalankan tetapi tidak semua jemaat melakukannya oleh karena kurangnya pemahaman yang benar tentang puasa, atau mereka hidup dengan mempraktikkan puasa yang benar, namun karena tidak memahami arti puasa yang sesungguhnya, maka mereka mengatakan bahwa mereka tidak berpuasa. Sehingga setiap kali ibadah puasa dilaksanakan jemaat yang datang dapat dihitung jumlahnya dengan jari.

\section{Metode Penelitian}

Penelitian ini adalah penelitian kualitatif dengan pendekatan grammatical analysis. grammatical analysis adalah "the first stage of determining the inner cohesion of the text is to analyze the relationships entween the individual units or terms in the 
next". (Osbone; 1991:19). Paradigma yang digunakan adalah paradigma naturalistik, yang pada hakikatnya merupakan suatu upaya untuk menemukan kebenaran atau untuk lebih membenarkan kebenaran. Kebenaran yang dimaksud adalah Kebenaran konsep Puasa yang benar berdasarkan Yesaya 58:1-12.

Teknik pengumpulan data dalam penelitian ini dilakukan dengan pengamatan atau partisipasi langsung dan penelaahan dokumen.

Analisis data yang digunakan dalam penelitian ini mengikuti langkah-langkah grammatical analysis. Penelusuran terhadap meaning dari setiap frasa akan sangat terlihat hal ini dengan Tujuan supaya dapat melihat atau mendapat sense dari meaning yang dimaksud berkenaan dengan konsep puasa yang benar.

\section{Hasil Dan Pembahasan}

\section{A. Pengantar Kitab Yesaya}

Kitab Yesaya merupakan salah satu kitab nabi-nabi yang secara terang-terangan menentang sikap umat Allah, namun sebelum melihat lebih jauh mengenai suara nabi perihal puasa, maka ada beberapa pokok dalam pengantar yang menolong pembaca untuk memahami isi Yesaya 58 :1-12.

\section{Latar belakang teks Yesaya 58: 1-12}

Umat Israel adalah umat pilihan Allah, kehidupan mereka penuh dengan aturan termasuk dalam hal berpuasa kepada Tuhan. Akan tetapi, dalam kenyataannya aturan tersebut seringkali diabaikan. Mereka melakukan puasa penuh dengan kepalsuan. Mereka merendahkan diri dihadapan Tuhan namun tidak dengan sepenuh hati. Oleh sebab itu, dalam teks ini nabi Yesaya diperintahkan oleh Tuhan untuk menyerukan alasan Allah tidak mendengarkan doa mereka, tidak mengindahkan ibadah mereka, serta menjelaskan kembali puasa yang Allah kehendaki sesungguhnya.

\section{Konteks Yesaya 58: 1-12}

Dalam bagian ini penulis akan uraikan konteks kitab Yesaya yang terbagi dalam dua bagian yaitu konteks dekat dan konteks jauh.

\section{Konteks dekat}

Konteks dekat dari Yesaya 58: 1-12 adalah Yesaya 59; 56: 9-12; 57 :1-13. Teks-teks tersebut memiliki keterkaitan terhadap teks yang akan penulis teliti. Dalam Yesaya 59 menjelaskan bahwa dosa umat Israel adalah penghambat dan perusak hubungan umat Israel dengan Tuhan Allah. Dosa adalah pemisah antar umat Israel dan Tuhan serta sumber dari segala kehancuran hidup umat Israel. Yesaya melukiskan kehancuran moral yang sangat mengerikan akan dialami oleh umat Israel pada zaman pemerintahan Manasye. Keberdosaan umat Israel seperti telur ular beludak yang memberikan dampak buruk kepada setiap orang yang percaya kepada mereka. Mereka murtad kepada Tuhan dan telah mengkhususkan setiap bagian tubuh mereka bagi kejahatan dan kefasikan. Oleh karena dosa mereka tersebut maka umat Israel tidak dapat untuk berdamai dengan Allah dan orang lain, serta damai sejahtera tidak pernah mereka nikmati dalam hati mereka (Yes. 59: 5-9).

Yesaya 56-59 menegaskan dosa bangsa Israel yang sudah merajalela baik dalam hal moral dan spiritual yang meracuni semua golongan. Kehidupan rohani Israel telah jauh dari kehendak Tuhan. Israel mengadakan ibadah yang tidak lagi sesuai dengan kehendak Tuhan. Israel melakukan ibadah yang berpusat pada diri sendiri. Ibadah Israel 
tidaklah dikenan oleh Tuhan karena mereka lebih mementingkan kepuasan diri sendiri dibandingkan dengan kehendak Tuhan. Israel lebih suka dipuji. Yesaya melihat adanya penyelewengan yang dilakukan oleh para pemimpin, sebab mereka memeras masyarakat Yahudi yang saleh secara kejam dan tidak bermoral.

Oleh sebab itu, Tuhan, Allah melalui Yesaya memberitahukan segala kesalahan yang diperbuat umat Israel. Bahkan dikatakan bahwa ketika mereka beribadah kepada Tuhan, juga kejahatan sambil mereka rancangkan. Akibatnya adalah ibadah yang mereka lakukan, doa yang mereka sampaikan tidak berkenan di hati Tuhan, pada akhirnya damai sejahtera yang mereka harapkan, tidak dapat dicapai oleh karena dosa dan pelanggaran mereka.

\section{Konteks Jauh}

Konteks jauh dari Yesaya 58: 1-12 adalah Yesaya 60: 1-22; 61: 1-11; 62: 1-12; 66: 1-14. Dalam teks-teks tersebut dijelaskan bahwa Tuhan Allah sesungguhnya sangat peduli dan perhatian kepada umat pilihanNya. Kedukaan sementara yang dialami oleh umat Israel akan digantikan dengan sukacita yang besar. Inilah bagian berkat yang akan diterima serta dialami oleh orang-orang yang percaya kepada Allah dan mengandalkan Tuhan dengan setia. Berkat Tuhan tersebut tidak terhitung jumlahnya, bahkan ketika la menyatakannya seringkali jauh melebihi dari yang telah dipikirkan dan diharapkan oleh manusia.

Yesaya menjelaskan bahwa kegelapan dunia akan dikalahkan oleh terang Israel. Terang ilahi akan membuat orang-orang dari bangsa-bangsa lain berhimpun ke Kerajaan Allah, dengan mempersembahkan semua milik dan talenta sebagai kurban syukur bagi Tuhan. Terang yang di maksud dalam hal ini adalah janji keselamatan dari Allah terwujud dalam diri Yesus Kristus yang menjadi manusia. Terang dan damai

sejahtera dari Allah akan dialami oleh umat tebusan Allah. Kasih karunia Allah menjamin keselamatan untuk manusia yang hidup dalam kebenaran ilahi. Tuhan dalam takhta kudusNya tidak mengharapkan korban dan atau pun menuntut Bait Suci sebagai kediamanNya. Akan tetapi yang Tuhan inginkan adalah kesungguhan hati umat Israel untuk bertobat dan percaya kepadaNya.

\section{B. Analisa Teks Yesaya 58: 1-12}

Dalam bagian ini penulis akan melakukan penelitian terhadap teks asli (bahasa Ibrani) dari Yesaya 58: 1-12 dan memaparkan pengertian yang terdapat dari teks tersebut, sebagai upaya untuk mendapatkan konsep puasa yang sesungguhnya.

\section{Definisi puasa}

Istilah puasa berasal dari bahasa Ibrani ditulis dalam bentuk צוֹ noun common masculine singular absolute. Puasa disebut sebagai kata benda karena merupakan karakter yang melekat dalam diri seseorang terwujud dalam tindakan sehingga timbul konsep penguasaan diri. Disebut sebagai laki-laki tunggal absolut karena dalam adatistiadat orang Israel, keturunan yang mendapat harta waris dari orang tuanya adalah anak laki-laki.

Maka umat Israel adalah satu-satunya umat pilihan yang telah diangkat oleh Allah untuk menjadi ahli waris Kerajaan Allah secara mutlak. Selain itu, dapat juga diartikan bahwa umat Israel yang melakukan puasa sangat penting sekali untuk memahami bahwa puasa bukan hanya sekedar berhenti dari makan dan minum. Akan tetapi umat 
Israel harus memahami bahwa puasa adalah suatu aktifitas untuk menghentikan diri dari aktifitas-aktifitas yang hanya membawa pada kesenangan atau keuntungan pribadi.

Dari pengertian tersebut dapat disimpulkan bahwa salah satu sifat yang harus dimiliki oleh umat Israel sebagai satu-satunya umat pilihan Allah yang akan mewarisi KerajaanNya adalah harus memiliki sikap hidup yang mampu untuk menguasai diri, mampu untuk menghindari, bahkan menghentikan diri untuk melakukan hal-hal yang hanya bermanfaat sesaat dan bersifat pribadi. Puasa yang Tuhan kehendaki bukan hanya pada hari-hari tertentu saja, akan tetapi setiap saat dan setiap waktu umat Israel melakukan puasa sesuai dengan yang Tuhan kehendaki. Karena umat Israel adalah umat pilihan Allah yang mutlak maka sikap hidup yang baik dan berkenan di hati Tuhan juga mutlak kepemilikannya dan pelaksanaannya.

\section{Dosa umat israel perihal puasa}

Umat Israel menjalani hidup dengan aturan-aturan yang Tuhan tetapkan, termasuk dalam hal puasa. Akan tetapi, seiring berjalannya waktu Tuhan memperhatikan bahwa umatNya melakukan kesalahan saat puasa. Kesalahan tersebut adalah sebagai berikut:

\section{a. Saat puasa, umat Israel masih tetap mengurus urusan sendiri (Yes. 58: 3c)}

Hukum dalam beribadah kepada Tuhan adalah hati, pikiran, dan perasaan serta seluruh aspek kehidupan semua terfokus kepada Tuhan dan tidak kepada yang lain (Kel. 20: 8-11). Demikian halnya dalam melakukan puasa. Namun pada kenyataannya, umat Israel tidak menaati perintah Tuhan tersebut. Mereka berpuasa sambil mengurus dan memikirkan hal-hal lain yang tidak tertuju kepada Tuhan. Terjemahan asli dari kata "mengurus urusanmu" dalam ayat ini adalah \#p,xe-Wac.m.Ti. Dua suku kata ini memiliki pengertian yang berhubungan satu sama lain, dengan bentuk kasus yang sama.

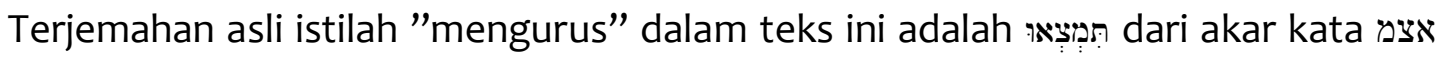
matsa (maw-tsaw), artinya adalah mendapat, menemui. Sedangkan istilah "urusanmu" terjemahannya adalah חקטֶ chephets (khay-fets) dengan pengertian menghendaki, menyukai. Kedua suku kata di atas memiliki kasus yang sama dalam penulisannya yaitu verb qal imperfect 2nd person masculine plural nou noun common masculine singular absolute. Artinya suatu pekerjaan yang akan dilakukan oleh orang kedua maskulin jamak yaitu umat Israel dan dalam teks ini menggunakan kata benda karena untuk menyatakan kepemilikan suatu sifat. Dalam terjemahan lain mengartikan kesenangan atau kesukaan.

Berdasarkan pengertian-pengertian di atas, maka dapat disimpulkan bahwa suatu sifat absolut yang dimiliki oleh umat Israel ketika berpuasa kepada Tuhan adalah kesenangan untuk mengusahakan perkara-perkara duniawi, misalnya urusan dalam rumah tangga, pekerjaan, usaha, sekolah dan lain sebagainya. Semuanya itu dipikirkan oleh umat Israel saat sedang menghadap Tuhan dalam berpuasa, sehingga menyebabkan munculnya keputusan Allah untuk tidak mengindahkan maupun memperhatikan perendahan diri yang dilakukan oleh umat Israel. 


\section{b. Saat puasa, umat Israel mendesak-desak semua buruh (Yes. 58: 3d)}

Kebiasaan buruk lainnya yang dilakukan oleh umat Israel saat berpuasa kepada Tuhan adalah "mendesak-desak semua buruh". Terjemahan asli "mendesak-desak"

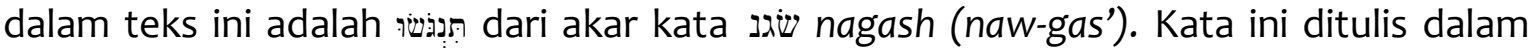
bentuk verb qal imperfect 2nd person masculine plural. Artinya suatu pekerjaan yang akan dilakukan oleh orang kedua maskulin jamak dalam hal ini umat Israel.

Mendesak-desak dalam pengertian lain adalah penindas, penekan, menggunakan atau mendesak dengan banyak permintaannya, banyak persyaratannya, mendesak dengan banyak tekanan. Dari pengertian tersebut dapat disimpulkan bahwa umat Israel tidak sepenuh hati berpuasa kepada Tuhan, karena pada saat mereka berpuasa ada aktifitas lain yang mereka lakukan adalah menghampiri para pekerja mereka dengan banyak persyaratan, dengan banyak tekanan. Ada suatu perbuatan nekad yang mereka lakukan adalah menjadi penindas, menjadi mandor tetapi bukan mandor yang baik.

\section{c. Saat puasa, umat israel sambil melakukan perbantahan dan perkelahian (Yes. 58: 4a)}

Salah satu natur manusia yang buruk adalah berbantah dan berkelahi. Kamus bahasa Indonesia mengartikannya dengan bertengkar mulut, adu tenaga dan katakata. Dalam teks ini, Tuhan mengatakan kepada umat Israel bahwa mereka saling berbantah dan berkelahi saat berpuasa. Istilah berbantah dalam teks ini ditulis dengan ? ריב particle preposition common masculine singular absolute. Artinya bahwa ada satu sifat yang selalu melekat dalam diri setiap orang adalah berbantah.

Biasanya perbantahan yang dilakukan tersebut berujung dengan hal yang tidak baik yaitu perkelahian. Hal tersebut dapat terjadi karena ada usaha atau kerja keras untuk mempertahankan pendapat sehingga terjadi persengketaan, pertikaian, perdebatan, perbantahan, pertengkaran, pertarungan dan perselisihan.

Demikianlah yang dilakukan oleh umat Israel saat berpuasa sehingga menyebabkan Tuhan marah dan tidak mau untuk mendengarkan serta mengindahkan puasa mereka. Oleh karena umat Israel tidak bisa mengendalikan diri saat berpuasa sehingga akhirnya terjadi perbantahan dan perkelahian dengan sesama, berjuang untuk kepentingan pribadi, berebut sesuatu yang tidak berfaedah bagi pertumbuhan rohani, berdebat dengan tidak mau kalah, berdiskusi tidak jelas, berbincang, dan membahas suatu pembahasan yang tidak penting.

\section{Akibat Dosa Umat Israel Perihal Puasa}

Adapun beberapa akibat yang dialami oleh umat Isarael saat melakukan puasa dengan tidak sungguh-sungguh adalah sebagai berikut:

\section{a. Puasa Umat Israel Tidak Diperhatikan Oleh Tuhan (Yes. 58: 3a)}

Tindakan Allah tidak memperhatikan puasa Israel disebabkan oleh ketidaksungguh-sungguhan umat Allah menghadap Dia. William B. Eendmans mengomentari hal ini mengatakan:

God told Isaiah to shout aloud with a voice like a trumpet and announce the sins of the nation. The people went to the temple, obeyed God's laws, fasted, and appeared eager to seek the Lord, but their worship was only an outward show. Their hearts were far from God (Ish.1: 10-15; 29:13; Matt 15: 8-9). When we 
worship because it is the popular thing to do, not because it is the right thing to do, then our worship becomes hypocritical.

Dengan motif penyembahan yang salah dari umat Allah dalam mengadakan ibadah mengakibatkan Allah tidak memperhatikan mereka. Kata tidak dalam teks Yesaya 58: 3a berasal dari bahasa Ibrani yaitu וְל (lo), dari akar kata לאי (lo') artinya adalah tidak, bukan. Tidak yang dimaksud dalam teks ini adalah sama sekali tidak, tidak pernah. Kata וְל (lo) ini ditulis dalam bentuk ? particle conjunction particle negative, merupakan kata larangan tetap yang telah di buat oleh Allah dalam bentuk yang mutlak tanpa memiliki unsur permintaan. Kata berikutnya adalah memperhatikan

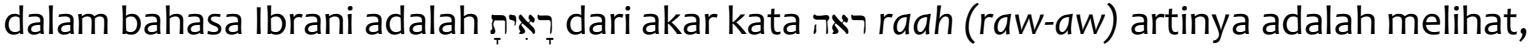
merasa.

Dalam terjemahan lain dikatakan melihat, mengerti, mempertimbangkan, menemui, menyaksikan, menjumpai, melihat, memandang, memeriksa. Dalam ayat ini kata ראה ditulis dalam bentuk verb qal perfect 2nd person masculine singular. Artinya suatu pekerjaan yang dilakukan dengan sempurna oleh orang kedua maskulin tunggal dalam hal ini adalah Allah yang dipercaya oleh Abraham, Yakub, Ishak serta seluruh umat Israel.

Berdasarkan pengertian di atas, maka dapat disimpulkan bahwa tindakan "tidak memperhatikan" merupakan suatu keputusan tetap dan telah dilakukan dengan sempurna oleh Allah. KetetapanNya tersebut yakni tidak melihat, mengerti, mempertimbangkan, menemui, menyaksikan, menjumpai, atau memandang umat Israel yang beribadah puasa kepadaNya.

\section{b. Perendahan Diri Umat Israel Tidak Diindahkan Oleh Tuhan (Yes. 58: 3b)}

Kata mengindahkan dalam bahasa aslinya adalah תרדָ dari akar kata ידע yada' (yaw-dah'), ditulis dalam bentuk tulisan verb qal imperfect 2nd person masculine singular. Suatu perbuatan yang akan dilakukan oleh orang kedua maskulin tunggal yaitu Allah. "Mengindahkan" artinya adalah tahu, kenal, mengetahui, memperhatikan. Dalam terjemahan lain disebut dengan keluarga, kekeluargaan, pertalian keluarga, mempelajari untuk mengetahui, mengakui, mengenal, menghargai.

Dari pengertian tersebut dapat disimpulkan bahwa puasa umat Israel tidak akan lagi diperhatikan oleh Tuhan. Puasa mereka tidak akan dipertimbangkan oleh Tuhan, karena Tuhan tidak mengenal mereka, bahkan Allah tidak akan mengakui mereka sebagai umatNya karena dosa-dosa yang telah mereka rancangkan dan lakukan. Apabila diumpamakan sebagai keluarga, maka Tuhan memutuskan hubungan keluarga tersebut dengan umat Israel, sehingga tidak akan ada lagi pertalian keluarga di antara keduanya.

\section{c. Suara Mereka Tidak akan Di Dengar Oleh Tuhan (Yes. 58: 4b)}

Yang dimaksud dengan istilah "tidak akan di dengar" dalam teks ini adalah dari akar kata עמש shama (shaw-mah) artinya mendengar, memperhatikan. Kata ini ditulis dalam bentuk ? bentuk kata kerja aktif yang berbentuk kausatif (sebab-akibat), artinya bahwa ada hubungan sebab akibat sehingga sesuatu terjadi. Oleh karena teks ini mengatakan bahwa Allah tidak akan mendengar suara umat Israel, maka kata tersebut mengandung arti kebalikan dari pengertian mendengarkan. 
Satu keputusan yang telah Tuhan tetapkan adalah "tidak akan mendengarkan suara umat Israel dari tempat tinggi". Hal ini sebagai akibat dari perbuatan umat Israel kepada Tuhan. Adapun alasan mendasar bagi Allah untuk tidak mendengarkan umat Israel adalah karena dosa dalam ibadah mereka, yang penuh dengan kepura-puraan, kemunafikan, dan hal mementingkan diri sendiri.

Sehingga Allah dengan sangat tegas mengatakan, "sangkamu cara kamu berpuasa menggerakkan Aku untuk mendengarkan doa-doamu?" (BIS: Yes. 58: 4b). Terkhusus dalam teks ini, memberikan suatu ketegasan keputusan Allah, yakni oleh karena kesalahan konsep puasa kepada Allah mengakibatkan suara umat Israel tidak didengarkan di tempat tinggi, yaitu di tempat kediaman Allah bertahta dalam kerajaanNya yang abadi.

\section{Konsep Puasa Umat Israel Yang Masih Tuhan Pertanyakan Kebenarannya \\ 1. Menundukkan Kepala Seperti Gelagah (Yes. 58: 5c)}

Istilah menundukkan kepala dalam teks ini adalah כפ kaphaph (kaw-faf), dengan pengertian haluan, tunduk kepada, menekukkan, membengkokkan, melengkungkan dari tingkat tinggi ketingkat yang lebih rendah. Kata ini ditulis dalam bentuk interrogative ? particle preposition כפ verb qal infinitive construct. Artinya bahwa ada satu tindakan menyampaikan pernyataan mengandung pertanyaan, dalam hal ini pernyataan tersebut disampaikan oleh Allah kepada umat Israel. Allah mengumpamakan tindakan umat Israel seperti gelagah. Gelagah yaitu sejenis tumbuhan rawa yang tingginya mencapai dua meter ataupun pohon bambu besar dengan ujung bambunya merunduk sampai ke tanah.

Demikianlah Tuhan mengumpamakan umat Israel saat berpuasa yakni secara lahiriah mereka menundukkan kepala sampai ke tanah, pertanda bahwa mereka menghormati Allah, namun hati mereka jauh dari Allah. Oleh sebab itu, dalam hal ini Allah menanyakan apakah hanya itu pengertian puasa yang dimengerti oleh umat pilihanNya? Karena sesungguhnya Allah pun telah memberikan aturan-aturan dan pengertian puasa tersebut kepada umat Israel sebelumnya.

\section{Membentangkan Kain Karung dan Abu Sebagai Lapik Tidur (Yes. 58: 5c)}

Satu kebiasaan sebagai ciri khas umat Israel yang menandakan bahwa mereka berkabung atau pun bertobat adalah ketika secara lahiriah mereka mengenakan kain kabung dan abu (Mat 11: 21). Kain kabung terbuat dari bulu kambing dengan warna yang kehitam-hitaman juga dapat terbuat dari karung goni. Seringkali jika penderitaan yang sangat hebat melanda, maka orang Israel mengenakan kain yang kasar tersebut langsung pada kulit tubuh mereka seperti yang dilakukan Ayub (Ayb. 16: 15). Hal tersebut menandakan bahwa mereka menyadari akan dosa-dosa mereka dihadapan Tuhan dan sangat merindukan sekali pengampunan dari Tuhan atas diri mereka.

Bahan lain yang menandakan secara lahiriah bahwa umat Israel berkabung ataupun bertobat adalah ketika mereka mengenakan abu baik di atas kepala maupun sebagai lapik tidur. Dalam Perjanjian Lama abu diartikan רפא epher dengan pengucapan "ay'-fer", diterjemahkan dengan abu atau pun ketidakbergunaan.

Istilah ini dipakai sebagai kiasan dengan pengertian yang tanpa harga (Yes. 44: 20), memuakkan (Ayb. 30: 19), kesengsaraan (Mzm. 102: 8; Yer. 6: 26), malu (2 Sam. 13: 19), bukti perendahan diri di hadapan Allah (Kej. 18: 27; Ayb. 42: 6) dan perasaan sedih karena berdosa (Dan. 9: 3; Mat. 11: 21). Abu digunakan dalam upacara untuk 
pembersihan (Bil. 19: 9-10, 17; Ibr. 9: 13). Abu hasil dari sisa korban bakaran khusus, disimpan dan dipakai dengan air mengalir untuk membersihkan dari kenajisan, dan sebagai tanda berpuasa (Yes. 58: 5; Yun. 3: 6).

\section{Konsep Puasa Yang Berkenan Di Hati Tuhan}

1. Puasa Adalah Tindakan yang Berhubungan dengan Kelepasan

Dalam Yesaya 58 terdapat beberapa kata kerja berhubungan dengan tindakan kelepasan, yaitu suatu perbuatan yang tidak merugikan atau pun menindas orang lain, dengan demikian membuktikan bahwa umat Tuhan memiliki kasih dan kepedulian terhadap sesama. Penjabaran tersebut menjadi konsep puasa yang berasal dari Tuhan, sebab dalam ayat enam mengatakan "Bukan! Puasa yang Kukehendaki ialah...". Artinya bahwa puasa yang dilakukan oleh umat Israel selama beberapa waktu itu tidaklah sesuai dengan yang Tuhan kehendaki. Oleh sebab itu dalam teks ini Tuhan menyampaikan konsep puasa yang berkenan dihatiNya yaitu sebagai berikut:

\section{Puasa Adalah Tindakan Membuka Belenggu-Belenggu Kelaliman (Yes. 58: 6a)}

Istilah membuka dalam terjemahan aslinya adalah חתפ pathach dengan pengucapan: paw-thakh. Artinya adalah melonggarkan, merenggangkan, menangkis, mematahkan, memecahkan, merusakkan, membuka secara paksa, memutuskan. Artinya bahwa belenggu-belenggu kelaliman yang telah mengikat umat Israel harus dipatahkan, dirusakkan, dibuka secara paksa, diputuskan dan diumumkan bahwa hal tersebut tidak akan dilaksanakan lagi.

Istilah membuka dalam teks ini ditulis dengan bentuk kasus פת verb piel infinitive absolute homonym 1. Dengan demikian istilah "membuka" yang dimaksud dalam teks ini adalah suatu tindakan yang harus dilakukan dengan sungguh-sungguh, penuh keseriusan dalam menghancurkan belenggu kelaliman yang telah mengikat selama ini. Kelaliman yang dimaksud adalah kebengisan, kekejaman, ketidakadilan, perbuatan yang tidak mengenal belaskasihan baik kepada manusia maupun kepada binatang. Segala jenis kelaliman tersebut harus dengan paksa dihancurkan, diputuskan, dilepaskan, supaya dapat leluasa untuk menghadap kepada Tuhan. Itulah puasa yang Tuhan mau yaitu menghentikan diri dari tindakan kelaliman.

\section{Puasa Adalah Tindakan Melepaskan Tali-Tali Kuk dan Mematahkan Setiap Kuk (Yes. 58: 6b, c) \\ Istilah "melepaskan" yaitu נתר verb hiphil infinitive absolute homonym 3. Artinya} bahwa Tuhan memerintahkan umat Israel supaya setiap ikatan-ikatan yang telah mereka buat selama ini untuk membebani sesama itu harus dilepaskan. Dalam terjemahan aslinya "melepaskan" adalah רתנ nathar dengan pengucapan: naw-thar dalam terjemahan lain diartikan bebas, lepas, langkah, lompatan, melepaskan, merusak.

Dengan demikian dapat diartikan bahwa puasa yang Tuhan maksud dalam teks ini adalah setiap ikatan-ikatan yang telah ada dan masih ada harus dibebaskan, dilepaskan. Sehingga akan tercipta langkah berikutnya yang akan mengarah pada puasa yang berkenan di hati Tuhan, dan hal tersebut yang akan menjadi lompatan bagi umat Israel untuk menghadap Tuhan dalam bentuk puasa. Dengan demikian dapat diartikan bahwa puasa yang Tuhan maksud adalah setiap ikatan-ikatan yang telah dibuat umat Israel untuk membebani sesamanya manusia atau bahkan dirinya sendiri, 
harus diputuskan sehingga tidak tersambung lagi, dirusak sehingga tidak dapat terpakai lagi, dan pada akhirnya puasa yang dilakukan akan berkenan di hati Tuhan.

Pribadi yang berharap kepada Tuhan tidak akan pernah mengabaikan perintah Tuhan. Adapun bagian dari yang Tuhan perintahkan adalah puasa dengan pegertian mematahkan setiap kuk yang telah dibuat selama ini. Arti dari istilah mematahkan adalah קתנ nathaq dengan pengucapan: naw-thak' (menjauhkan diri), dalam pengertian lain yaitu: retak atau putus. Artinya bahwa sesuatu yang telah terjalin selama ini, terikat atau pun terbuat selama ini diretakkan dengan sungguh-sungguh bahkan diputuskan dengan sungguh-sungguh sehingga tidak akan dapat terjalin lagi.

Perintah tersebut dapat terlihat dari bentuk kasus istilah ini yaitu נתק verb piel imperfect 2nd person masculine plural. Dengan demikian dapat diartikan bahwa puasa Israel yang Tuhan kehendaki adalah membuat retak dengan sungguh-sungguh semua kuk yang telah di buat selama ini, membuat putus semua ikatan kuk yang telah dibuat selama ini. Puasa yang Tuhan kehendaki adalah kebebasan setiap pribadi dari segala beban-beban duniawi yang di buat terhadap sesamanya, karena Tuhan tidak pernah membebani umatNya dengan segala hal yang lebih berat dari kemampuannya sendiri.

\section{E. Puasa Adalah Tindakan Memperhatikan Sesama}

1. Puasa Adalah Memberi Pakaian Bagi yang Tidak Punya Pakaian (Yes. 58: 7b)

Suatu hal yang tidak boleh terlepas dari kehidupan setiap orang adalah memberi. Bahkan dalam kesusahan atau kesukaran sekalipun Tuhan mengehendaki supaya ketika ada orang yang minta pertolongan terhadap sesamanya, maka sesamanya tersebut harus mau dan rela untuk memberi. Demikian yang Tuhan maksud dalam teks ini adalah bahwa puasa merupakan sifat yang ada dalam diri umat Israel untuk mau peduli terhadap sesamanya dan bukan hanya pada diri sendiri.

Hal ini terbukti dari bentuk tulisannya yaitu ? particle conjunction particle

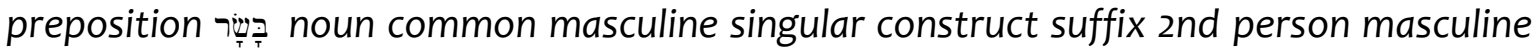
singular. Artinya bahwa umat yang ingin menghadap Tuhan dalam puasa harus memiliki sikap rela berkorban bagi sesamanya, rela berbagi kepada sesamanya, rela untuk memperhatikan kebutuhan sesamanya dan semua untuk kebutuhan sesamanya demi nilai kebersamaan. Oleh karena hidup bukan hanya untuk diri sendiri tetapi untuk Tuhan dan sesama.

\section{Puasa Adalah Tindakan Untuk Tidak Menyembunyikan Diri Terhadap Saudara (Yes. 58: 7c)}

Istilah menyembunyikan dalam teks ini adalah berasal dari kata מלע 'alam dengan pengucapan: aw-lam', artinya adalah harta benda yang terpendam, senjata tersembunyi, rahasia. Artinya umat Israel memiliki harta yang tidak dilihat oleh orang lain, bahkan peralatan untuk perlindungan diri mereka berada pada tempat yang tersembunyi dan tidak diketahui orang sama sekali. Istilah ini ditulis dalam bentuk עלם verb hithpael imperfect 2nd person masculine singular. Artinya bahwa adanya tindakan yang dilakukan dalam bentuk refleksif (saling memperhatikan) oleh orang ke dua maskulin tunggal, dalam hal ini umat Israel.

Dengan demikian "tidak menyembunyikan diri" yang di maksud dalam hal ini, adalah setiap umat Israel harus saling memperhatikan kebutuhan sesamanya dengan tidak menyembunyikan serta memendam segala kemampuan diri untuk menolong sesama. Umat Israel bukan pribadi yang sempurna namun bukan dalam arti bahwa 
mereka sama sekali tidak dapat melakukan sesuatu, oleh karena pertolongan Tuhan maka umat tersebut bisa. Maka pertolongan yang Tuhan anugerahkan tersebut juga dipergunakan untuk menolong sesama yang membutuhkan uluran tangan.

\section{Puasa Adalah Tindakan Menyerahkan Kepada Orang Lapar yang Diinginkan Sendiri (Yes. 58: 10a) \\ Memperhatikan sesama tidak hanya dengan perkataan saja bahkan bukan} dengan perkataan keagamaan. Memperhatikan harus dibuktikan melalui perbuatan. Istilah menyerahkan dalam bagian ini bersal dari kata קופ puwq, dengan pengucapan: pook, artinya adalah mengeluarkan, menghasilkan, membawa, menunjukkan, melengkapi dengan perkakas, menyediakan, memberikan, mengadakan, membuka. Istilah ini ditulis dalam bentuk kasus ? particle conjunction פerb hiphil imperfect 2nd person masculine singular jussive in form, not meaning apocopated homonym 2.

Artinya bahwa Tuhan menghendaki supaya umat Israel melakukan suatu pekerjaan yaitu menyerahkan kepada orang lapar apa yang mereka inginkan sendiri. Dengan demikian istilah menyerahkan yang dimaksud dalam teks ini adalah umat Israel Tuhan perintahkan untuk peduli kepada orang-orang yang butuh makanan. Ketika makanan ada maka perlu dikeluarkan untuk disajikan lengkap dengan semua peralatan makan, bahkan jika makanan belum jadi maka perlu untuk dikelola bahan makanan yang ada untuk mengadakan ataupun menghasilkan makanan yang dibutuhkan sehingga orang lapar tersebut dapat makan dan menjadi kenyang.

\section{4. $\quad$ Puasa Adalah Tindakan Memuaskan Hati Orang yang Tertindas (Yes 58: 10a)}

עבש Istilah memuaskan dalam teks ini berasal dari bahasa Ibrani yaitu עבש saba' sabea' artinya adalah mengenyangkan, memenuhi, meyakinkan, kekenyangan, kejenuhan, kebosanan. Artinya bahwa ada suatu tindakan dari umat Israel untuk membuat kenyang dengan memenuhi kebutuhan orang lain tersebut, bahkan sampai ia kekenyangan, jenuh dan bosan untuk menikmati makanan yang ada tersebut. Tujuannya adalah untuk meyakinkan bahwa orang lain tersebut benar-benar dipedulikan oleh sesamanya.

Istilah tersebut ditulis dalam bentuk kasus שבע verb hiphil imperfect 2nd person masculine singular. Artinya bahwa ada suatu tindakan yang dilakukan oleh orang kedua maskulin tunggal berdasarkan suatu penyebab sehingga ada akibatnya. Artinya bahwa oleh karena di sekitar umat Israel ada orang-orang yang tertindas, teraniaya bahkan dengan sengaja disengsarakan, maka umat Israel tidak boleh menutup mata untuk melihat dan memperhatikan mereka tersebut. Akan tetapi umat Israel harus membuat orang-orang tersebut seperti tidak tertindas dan teraniaya, dengan menyediakan makanan sampai mereka kenyang. Bahkan jika dapat supaya mereka diyakinkan sampai benar-benar yakin bahwa kelepasan akan mereka alami, kemerdekaan akan mereka nikmati, sehingga dengan demikian akan terpancar sukacita terhadap harapan yang ada di hati mereka.

\section{F. Faedah Puasa Yang Berkenan Di Hati Tuhan}

1. Kehadiran Tuhan akan Melindungi Dari Segala Penjuru (Yes. 58: 8b)

Dalam teks ini, Tuhan berjanji bahwa orang-orang yang hidup dengan tepat dan benar dihadapanNya, akan mendapatkan perlindungan sejati. Dalam Alkitab Bahasa 
Indonesia sehari-hari mengatakan "Aku akan menyertaimu untuk menyelamatkan kamu, KehadiranKu akan melindungi kamu dari segala penjuru." (Yes. 58: 8b)

Perlindungan yang Tuhan maksud dalam hal ini yaitu dengan menyatakan kebenaranNya sebagai bagian umat Israel tersebut. Hal ini terlihat dalam bentuk katanya yaitu צִ noun common masculine singular construct suffix 2nd person masculine singular. Artinya bahwa kebenaran merupakan sifat yang telah melekat dalam diri Allah dan kebenaranNya tersebut ditujukan kepada umat Israel yang melakukan puasa berdasarkan kehendakNya. KebenaranNya itulah yang ajan membela umatNya. Dalam teks ini mengatakan bahwa "kemuliaan Tuhan barisan belakangmu" (Yes. 58: 8b). Istilah kemuliaan dalam teks ini adalah keagungan, kecemerlangan,

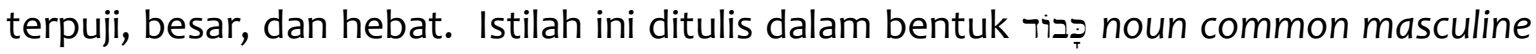
singular construct. Dengan pengertian kata benda maskulin tunggal konstruk. Disebut kata benda dalam teks ini karena kemuliaan merupakan sifat Allah yang melekat dalam diriNya, hanya Dialah satu-satunya yang memiliki kemuliaan, keagungan maupun kecemerlangan baik di bumi maupun di surga dan itulah yang akan membentengi umat yang melakukan kebenaran tersebut.

\section{Doa dan Seruan Umat Di Dengar dan Dikabulkan Oleh Tuhan (Yes. 58: 9a)}

Orang percaya selalu melakukan komunikasi kepada Tuhan dalam segala waktu dan tempat. Demikian halnya umat Israel waktu itu, mereka senantiasa berkomunikasi kepada Tuhan, terlebih dalam kesesakan yang mereka alami. Ketika mereka berseru memanggil nama Tuhan untuk memohon pertolongan Tuhan, maka janji firman Tuhan berkata "Tuhan akan menjawab,... . dan la akan berkata ini Aku" (Yes 58: 9a) Satu hal yang perlu diketahui oleh umat Israel bahwa janji Allah tidak pernah la ingkari dan selalu la tepati. Bahkan lebih dari apa yang di minta oleh umatNya itulah yang dianugerahkanNya.

Istilah menjawab dalam teks aslinya adalah hn[ yang artinya jawaban, menjawab, membalas, memberikan kesaksian. Istilah kata ini ditulis dalam bentuk ענה val imperfect 3 rd person masculine singular homonym 1. Artinya bahwa Tuhan akan menjawab setiap doa dan seruan umatNya. Tuhan memberikan janji kepada umat yang melakukan puasa yang benar akan mendapat respon dari Tuhan dengan menjawab ataupun membalas setiap permohonan dan doa mereka kepadaNya. Bahkan Tuhan akan memberikan kesaksian bahwa umat Israel adalah umat kesayanganNya, umat pilihanNya dan yang selalu diperhatikanNya.

\section{Kegelapan Di Sekeliling akan Menjadi Seperti Siang (Yes. 58: 8a; 10b)}

Siang dan malam telah Tuhan ciptakan dari awal, semua berguna untuk manusia. Dalam perjalanan kehidupan kesedihan, kedukaan dan hal-hal lainnya yang bersinonim dengan itu, disamaartikan dengan gelap atau kegelapan. Kamus bahasa Indonesia mengartikan kegelapan sebagai tempat yang gelap, suatu suasana yang ricuh, juga suatu situasi yang sulit untuk mencari jalan pemecah. Oleh sebab itu, dalam teks ini Tuhan mengatakan bahwa kegelapan disekitar umat Israel akan menjadi seterang siang. Kegelapan dalam teks Ibrani diartikan dengan kegelapan, kemuraman, kesuraman, kemurungan, suram, muram, murung.

Istilah tersebut ditulis dalam bentuk ? אִפלָלה particle conjunction noun comon feminine singular construct suffix 2nd person masculine singular. Artinya bahwa kegelapan merupakan kata benda feminin tunggal konstruk yang ditujukan kepada 
orang kedua maskulin tunggal. Dengan demikian dapat dikatakan bahwa kegelapan yang Tuhan maksud adalah kemuraman muka, hati dan perasaan, kesuraman dan kemurungan yang terpancar dari mereka akan diubah menjadi sukacita besar dan benar-benar menyenangkan mereka.

\section{Mendapat Pemeliharaan Tuhan (Yes. 58: 11)}

Tuhan adalah pencipta langit dan bumi beserta segala isinya, dalam penciptaanNya Allah juga menyatakan kasihNya melalui pemeliharaanNya. Dalam kitab Yehezkiel 34 dan Yohanes 10 serta Mazmur 23, menjelaskan tentang kasih dan pemeliharaan Tuhan bagi umatNya ketika la menuntun, mengarahkan dan memelihara dengan sungguh-sungguh umatNya. Istilah menuntun dalam bahasa aslinya diartikan dengan peranan penting, petunjuk, menuntun, menjadi penunjuk jalan, mengemudikan. Istilah tersebut ditulis dalam bentuk? particle conjunction נחה verb qal waw consec perfect 3rd person masculine singular suffix 2nd person masculine singular homonym 1. Artinya bahwa tuntunan yang akan dilakukan oleh Tuhan dahulu telah dilakukanNya ketika la mengeluarkan umat tersebut dari bangsa Mesir, dan tuntunan demikian akan Tuhan lakukan lagi kepada umat Israel. Sehingga diharapkan supaya umat tersebut bersungguh dalam berpuasa kepada Tuhan, maka Tuhan akan menuntun mereka lagi.

\section{Kesimpulan}

Berdasarkan pengertian-pengertian di atas maka penulis menyimpulkan bahwa puasa yang berkenan di hati Tuhan adalah dilakukan oleh setiap orang yang telah dipilih dan ditetapkannya sebagai ahli waris kerajaannya. Puasa bukan hanya sekedar berhenti dari aktivitas makan dan minum, namun perhentian diri dari memikirkan dan mengurus segala hal yang berbau duniawi. Puasa bukan hanya sekedar rutinitas yang secara lahiriah terlihat begitu rohani, tetapi sesungguhnya dalam hati masih memikirkan dan mengurus kebutuhan-kebutuhan jasmaniah yang semua demi keuntungan pribadi.

Puasa yang berkenan di hati tuhan adalah tindakan dari hati setiap orang dengan penuh ketulusan untuk memperhatikan dan mempedulikan kebutuhan sesamanya. Puasa adalah suatu aktifitas memberi kelepasan dan kebebasan bagi sesama sebagai bukti ketidaksewenang-wenangan terhadap sesama. Hal ini dapat dilakukan dengan sukacita oleh orang-orang yang memahami bunyi firman tuhan demikian: "namun aku hidup, tetapi bukan aku sendiri yang hidup, melainkan Kristus yang hidup di dalam aku" (gal. 2: 20a). Puasa adalah suatu hal yang semestinya diperhatikan dan dipraktikkan oleh setiap orang yang percaya kepada allah. Puasa bukan hanya sikap yang tertanam dalam diri seseorang tetapi suatu perbuatan yang dapat dilihat dan dirasakan oleh orang lain. Dalam melakukan puasa, maka kefokusan hati pikiran dan seluruh eksistensi kehidupan yang melakukan puasa benar-benar tertuju kepada allah. Dengan demikian puasa yang dilakukan tersebut berkenan di hati tuhan dan diberkati oleh tuhan, sehingga akan menghasilkan kehidupan yang lebih baik lagi. Oleh sebab itu, sebagai orang kristiani yang hidup di dalam kristus sangat perlu untuk memperhatikan dengan seksama keinginan hati Tuhan yang harus dilakukan dalam hidup bahkan terlebih saat puasa. Kebenaran setiap umat dalam melakukan kehendak tuhan akan mendapatkan berkat dan faedah yang berkelimpahan dan semua itu tidak dapat diberikan oleh siapapun serta tidak dapat digantikan oleh apapun. 


\section{KEPUSTAKAAN}

Baker D. L,

$2013 \quad$ Kamus Singkat Ibrani-Indonesia, Jakarta: BPK Gunung Mulia

Boeker T.G.R, 1987 Bahasa Ibrani Jilid 1 Edisi, Batu: YPPII

Brown Francis, 1978 The New Brown Driver Briggs Gesenius Hebrew and English Lexicon, Indiana: Associated Publisher and Authors

Douglas J. D,

2013

Ensiklopedi Alkitab Masa Kini Jilid I A-L, Jakarta: Yayasan Komunikasi Bina Kasih

Eendmans William B,

1992 Commentary of The Old Testament, (Michigan: Publishing Company, Grand Rapids, 1986) 645T.G.R Boeker, Bahasa Ibrani Jilid II, Batu: YPPII,

Harris R. Laird,

1980 Theological Wordbook Of the Old Testament Vol 1, Chicago: Moody Pree Jian Wiharja, $2001 \quad$ Puasa: Aktifitas Senyap, Jakarta: BPK Gunung Mulia

Harrison Everett F, 2005 The Wycliffe Bible Commentary Vol.2 Malang: Penerbit Gandum Mas

J. I. Packer, dkk., 2001 Ensiklopedi Fakta Alkitab Bible Almanac 2, Malang: Gandum Mas

Joseph Owens John 1994

Analytical Key To The Old Testament Vol. 4 Michigan: Baker Book House

Lee Beall James, $1980 \quad$ Puasa, Bandung: Kalam Hidup

Prince Derek, 1994 Berpuasa Mengapa Dan Bagaimana, Jakarta: Yayasan Pekabaran Injil Immanuel

Van Gemeren Willem A,

$1984 \quad$ New International Dictionary of Old Testament Theology and

Pe Green Jay,

$1718 \quad$ The Interlinear Bible Hebrew/English Vol 3, Michigan: Baker Book House, 1981

\section{Internet}

- $\quad$ http//aleichem.blogspot.co.id. Ebenhaizer Nuban Timor, "Masa Puasa Kristen", Diakses 11 Juni 2016

- $\quad$ http/aleichem.blogspot.co.id.html,"puasa-menurut-Alkitab", Diakses 2 Juli 2016 